\title{
Is there a labor shortage?
}

\author{
Michael Horrigan ${ }^{1} \cdot$ Misty Heggeness ${ }^{2} \cdot$ Kate Bahn $^{3} \cdot$ Michael R. Strain ${ }^{4}$
}

Published online: 20 January 2022

(c) National Association for Business Economics 2021

\begin{abstract}
A panel discusses ongoing and prospective developments in the US labor market. Michael Horrigan points out that job losses in the COVID recession were heavily concentrated among women, minorities, and less-educated workers. In turn, these groups have shown less progress regaining jobs, and many have left the labor force. Horrigan shows that the industry connection between vacancies and wage increases is not at all tight, suggesting that traditional explanations that labor shortages are a matter of wages not clearing the market needs to be modified. Misty Heggeness notes that much of the weakness in women's recent labor force participation has been by working mothers, but that their behavior has not been radically different than in the past. Policies that address the concerns of working mothers could lessen the possibility of swings like those recently seen. Kate Bahn expands to discuss more specific such policies, including paid leave, paid sick leave, more predictable work schedules, greater income support, as well as a revival of unions, as means to not only alleviate hardship, but also to increase labor market efficiency. Michael Strain contends that federal policy greatly enhanced consumer demand, but the income support programs, along with other problems, have restricted supply, leading to some of the distortions observed in the labor market. While he supports some of the policies proposed by other panelists, he is leery about the effects of specific government programs that have been offered.
\end{abstract}

Keywords Labor market $\cdot$ Wages $\cdot$ Female employment $\cdot$ Participation

\section{Mike Horrigan}

Good morning. It is an absolute pleasure to be here in person. It's been a while for all of us. I have five topics. I'm going to talk about the nature of employment losses from

Taken from the transcript of the session Is There Really a Labor Shortage? Held at the NABE Annual Meeting on September 28, 2001. Diane Lim presided. All views expressed are those of the speakers and do not reflect those of the U.S. Census Bureau.

Michael Horrigan

horrigan@upjohn.org

Misty Heggeness

misty.heggeness@gmail.com

Michael R. Strain

Michael.Strain@AEI.org

1 Upjohn Institute, Columbus, OH, USA

2 US Census Bureau, Washington, DC, USA

3 Washington Center for Equitable Growth, Washington, DC, USA

4 American Enterprise Institute, Washington, DC, USA
February to April last year, then the so-called "She recession," followed by a look at the nature of long-term unemployment, then the problems of what I call the "near" unemployed, and finally the broad question of whether there is a labor shortage.

\subsection{The 2020 employment losses}

First a look at the broad moves in payroll employment. Figure 1 indexes the level at 100 in December 2007. We lost 22.2 million jobs between February and April 2020. About $76 \%$ of the jobs lost were regained as of August. Figure 2 examines the size of the 2020 job losses across four-digit industries, grouped by their average weekly wage as reported in the QCEW.

You were low wage if your average weekly wage in your industry paid less than $2 / 3$ of the national average, between $2 / 3$ and 1.8 , I called you middle. And above that, I called you high wage. Just based on that simple statistical discrimination, I found $64 \%$ of the job losses were in low wage industries. To give you a more real aspect to it, I list the top ten industries in terms of employment declines 


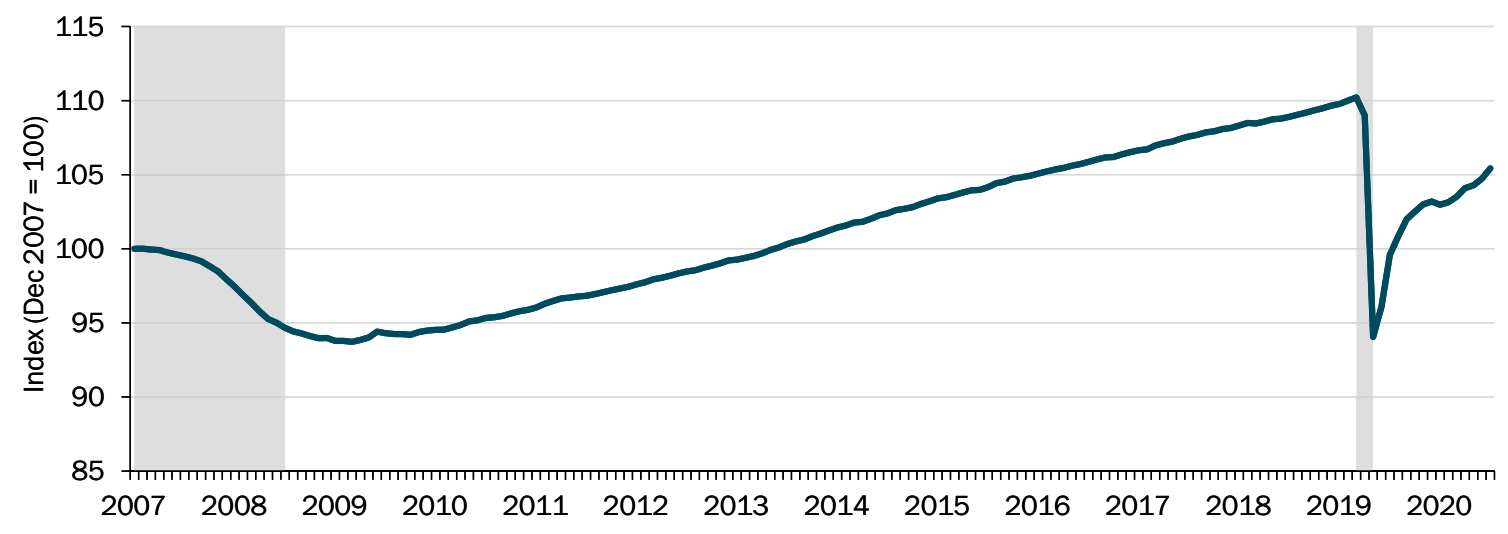

Source: Bureau of Labor Statistics Current Employment Survey \& Upjohn Institute

Fig. 1 Non-farm employment index

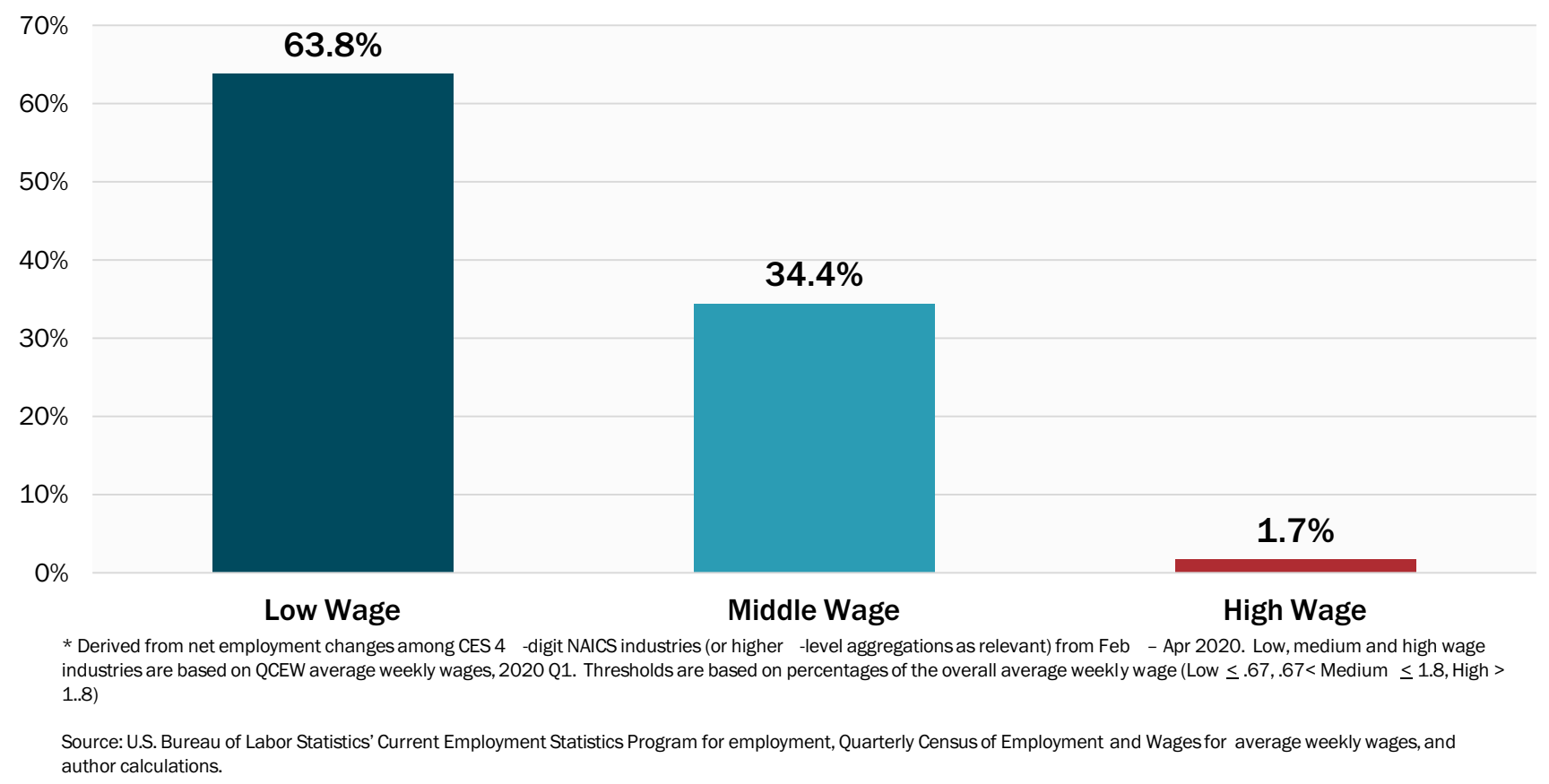

Fig. 2 64\% of job losses from Feb to April 2020 were in low wage* establishments

between February and April, regardless if they were low, middle, or high wage (Table 1).

And you can see, for example, offices of dentists really suffered in the beginning parts of the recession until they figured out how to come back in terms of providing services. But in terms of low wage, you see restaurants, you see traveler accommodation, clothing stores, daycare services, and drinking places that are perennial lower wage.

\subsection{The She Recession}

To move on, it's been called the She Recession. I don't dispute that. It's a very clever term in terms of capturing the essence of what happened between February and April, and what's going on now. A less sexy term is what I call it, basically, those with less than a BA, with particular impacts on women and minorities recession. 
Table 1 Ten industries accounted for over half of the employment declines from February to April 2020

\begin{tabular}{lll}
\hline Industry & $\begin{array}{l}\text { Employment change Feb-April 2020 } \\
\text { (thousands) }\end{array}$ & $\begin{array}{l}\text { Cumulative change as a percentage of } \\
\text { total employment change, Feb-April } \\
2020\end{array}$ \\
\hline Restaurants and Other Eating Places & $(5254)$ & 24.7 \\
Employment Services & $(1122)$ & 29.9 \\
Other Amusement and Recreation Industries & $(898)$ & 34.1 \\
Traveler Accommodation & $(891)$ & 38.3 \\
Clothing Stores & $(634)$ & 41.3 \\
Personal Care Services & $(613)$ & 44.2 \\
Offices of Dentists & $(555)$ & 46.8 \\
Special Food Services & $(384)$ & 48.6 \\
Child Day Care Services & $(373)$ & 50.3 \\
Drinking Places (Alcoholic Beverages) & $(338)$ & 51.9 \\
\hline
\end{tabular}

Source U.S. Bureau of Labor Statistics' Current Employment Statistics Program, seasonally adjusted data

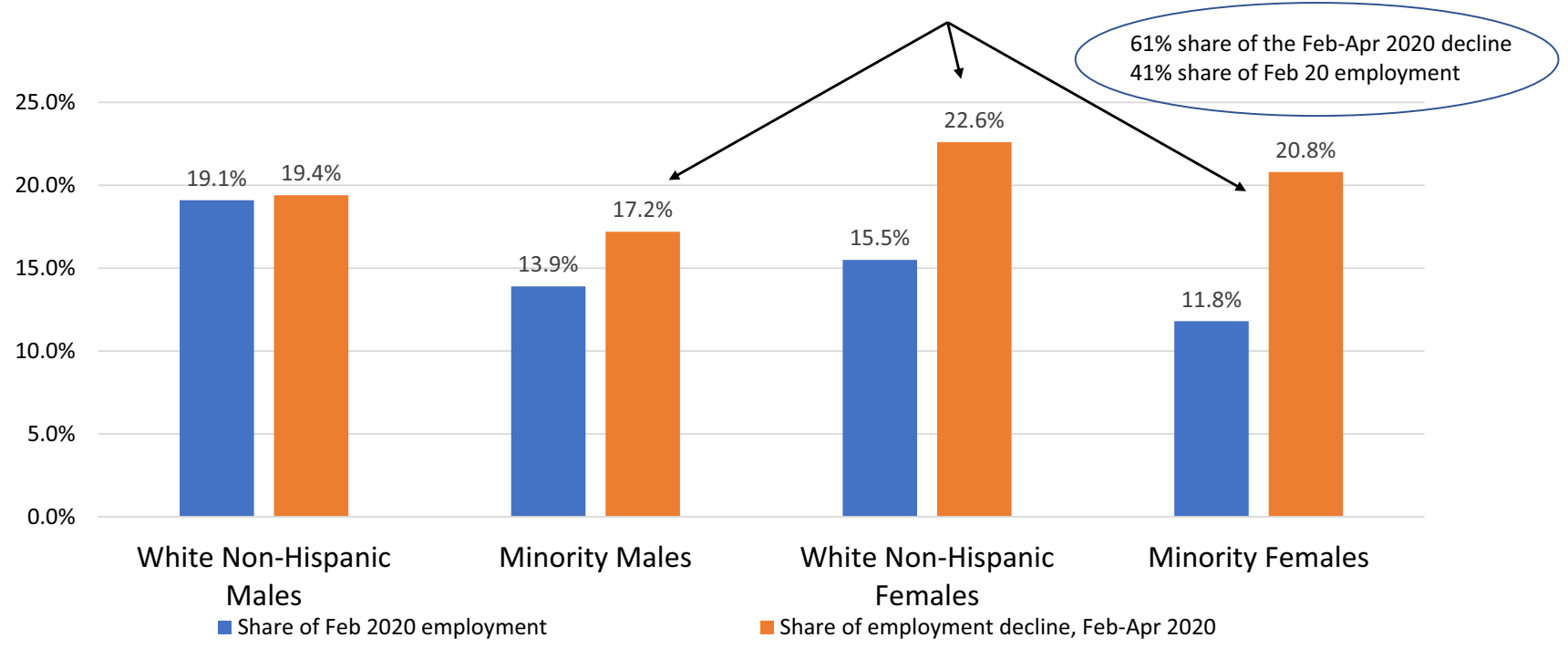

Source: U.S. Bureau of Labor Statistics' Current Population Survey Program. Not seasonally adjusted data.

Fig. 3 Females with less than a BA and minority males had a disproportionate share of the employment declines early in the pandemic recession

That's not quite as catchy a phrase. But it's still the same kind of impact. And what I have in Fig. 3 is a device that I'll repeat in many slides: showing the share of employment in February 2020 for a number of groups, and next to it the share of the total employment declines from February to April that was experienced by that group.

What you can see, for example, is that minority females represented $11.8 \%$ of employment, but accounted for $21 \%$ of the employment decline. These three groups, minority males, white, non-Hispanic females, and minority females, had a $61 \%$ share of the decline.
In Fig. 4 I compare the absolute number of jobs lost in each of the groups in Fig. 3 to the number of jobs regained since April 2020. What you see is that females in particular have had a relatively hard time regaining the employment that they lost at the beginning of the recession. So what I find also interesting is if you take a look at the groups with a BA or more, their employment losses were far less.

But among that group, out of the total, what you see is among those groups, whites, white males and females, and I divided it in terms of non-Hispanic, what you find is that 


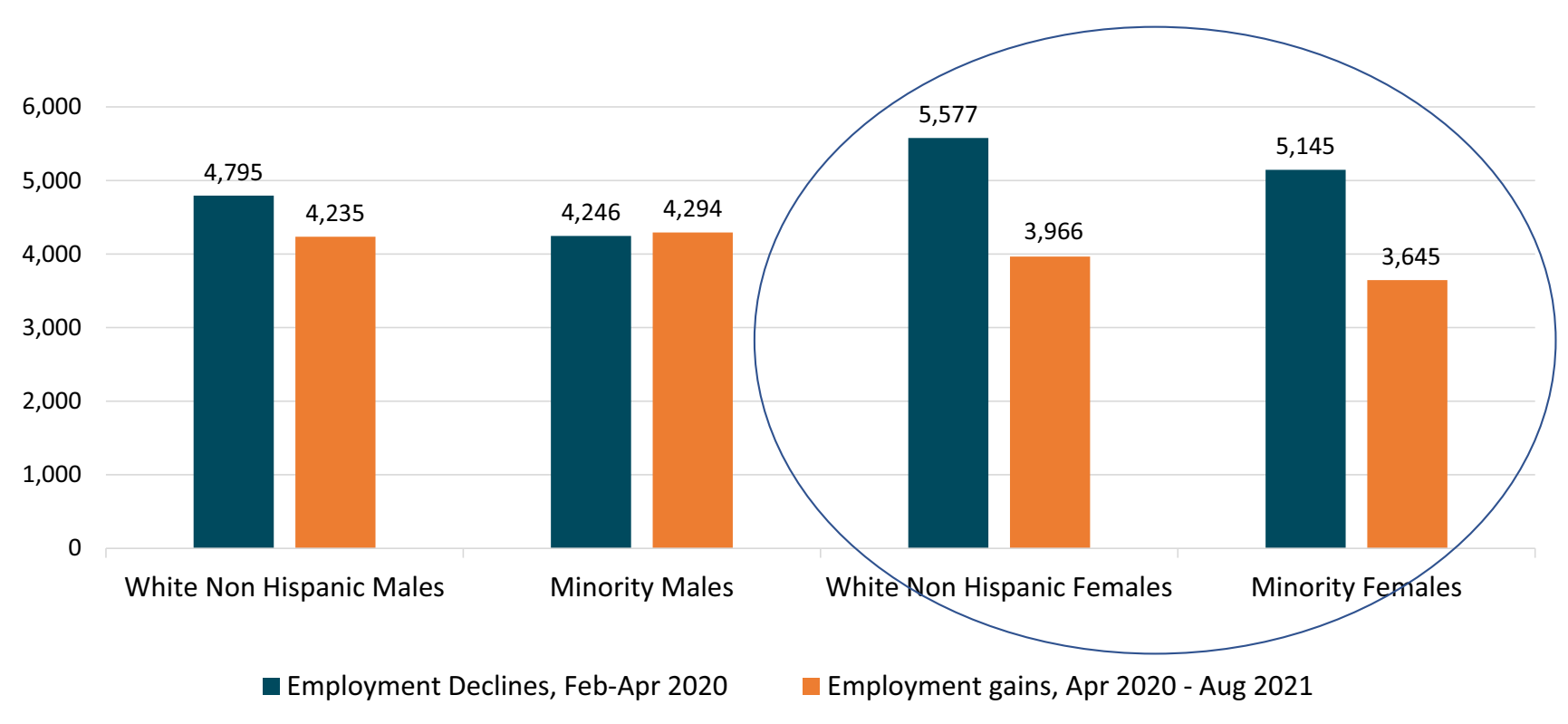

Source: U.S. Bureau of Labor Statistics' Current Population Survey Program. Not seasonally adjusted data.

Fig. 4 Females with less than a BA have had an especially difficult time regaining employment since April 2020

females have had a relatively harder time regaining their employment.

\subsection{Long-term unemployment}

Long-term unemployment is a key issue out of any recession. The Great Recession was a good example, we had about $45 \%$ of the unemployed at one point were long-term unemployed, 27 weeks or more (Fig. 5). That rate has actually been coming down in recent months. Right now, the long-term unemployed are $37.3 \%$ of the unemployed. So a little bit of progress there. But it in terms of who is it impacting, the same kind of story is about to emerge. What you find (Fig. 6) is that among those with less than a BA,

60.0

50.0

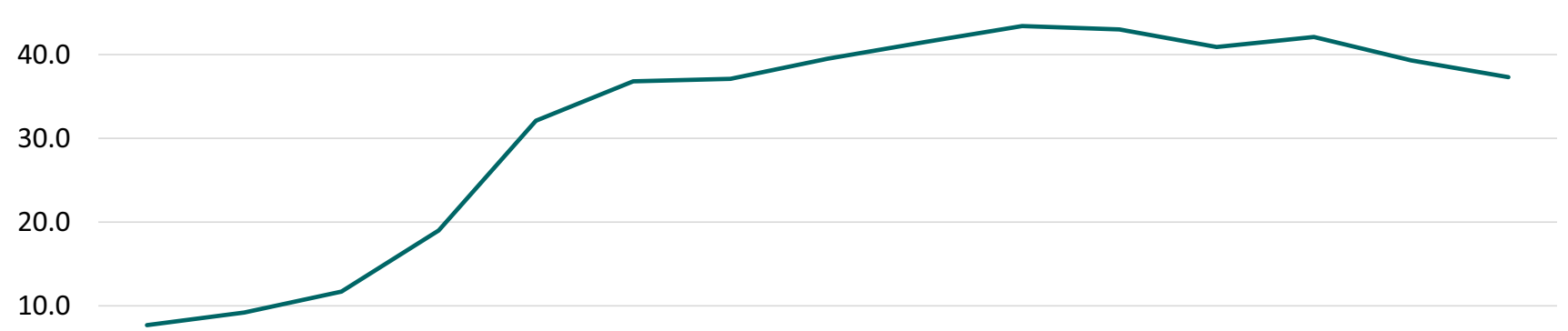

0.0

Jun-20 Jul-20 Aug-20 Sep-20 Oct-20 Nov-20 Dec-20 Jan-21 Feb-21 Mar-21 Apr-21 May-21 Jun-21 Jul-21 Aug-21

Source: U.S. Bureau of Labor Statistics' Current Population Survey Program. Seasonally adjusted data.

Fig. 5 Percentage of unemployed out of work 27 weeks or longer 


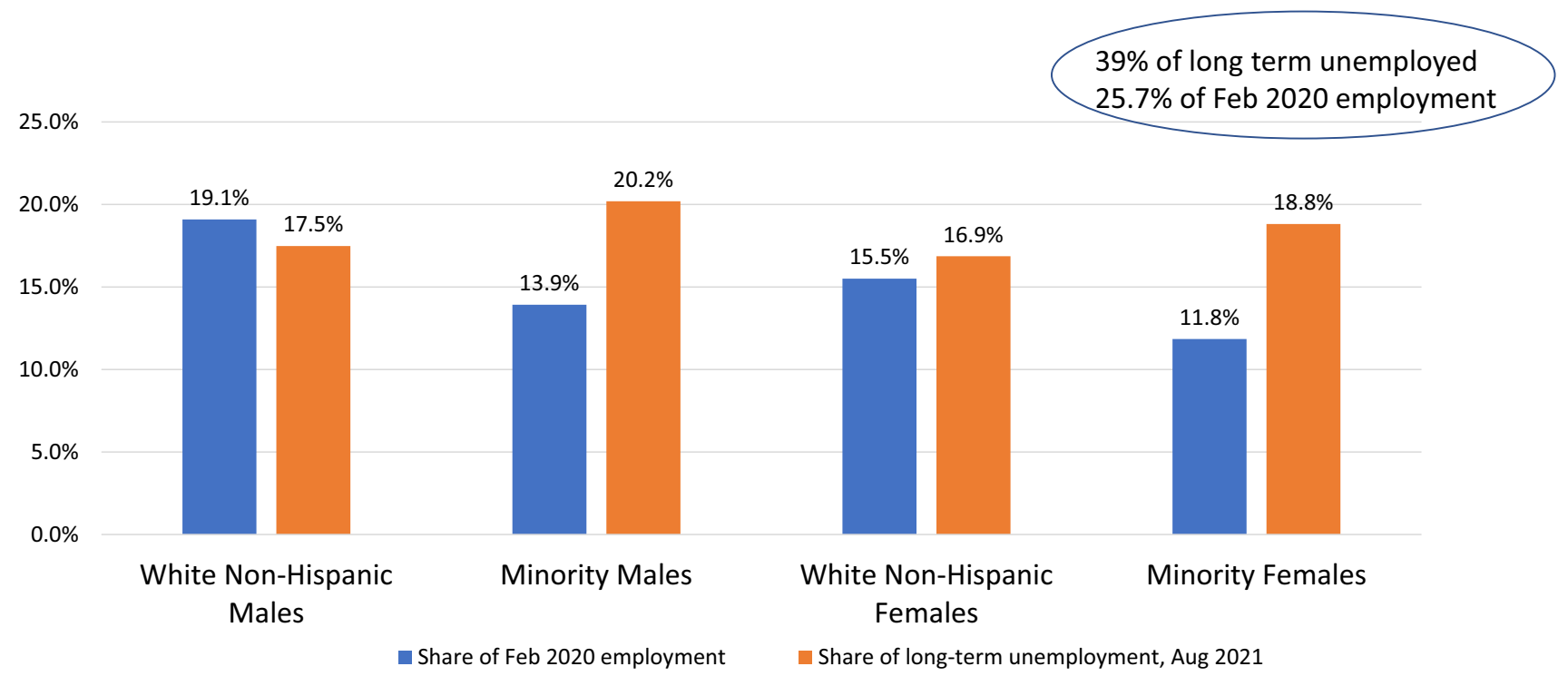

Source: U.S. Bureau of Labor Statistics' Current Population Survey Program. Not seasonally adjusted data.

Fig. 6 Among those with less than a BA, minorities make up a disproportionate share of long-term unemployment

minorities pick up a disproportionate share of long-term unemployment.

\subsection{The "Near" unemployed}

If you remember, between February and April 2020, when people were losing their jobs, if they were laid off, but they were expecting recall, whether they looked for work or not, it didn't matter, they were unemployed.

That's the definition. If you were laid off, and you were not expecting recall, and you were not searching for work, probably because of a thing called the pandemic, and the governor in your state probably said, "Stay home," you were actually classified appropriately as being out of the labor force.

$12,000.0$

$10,000.0$

$6,000.0$

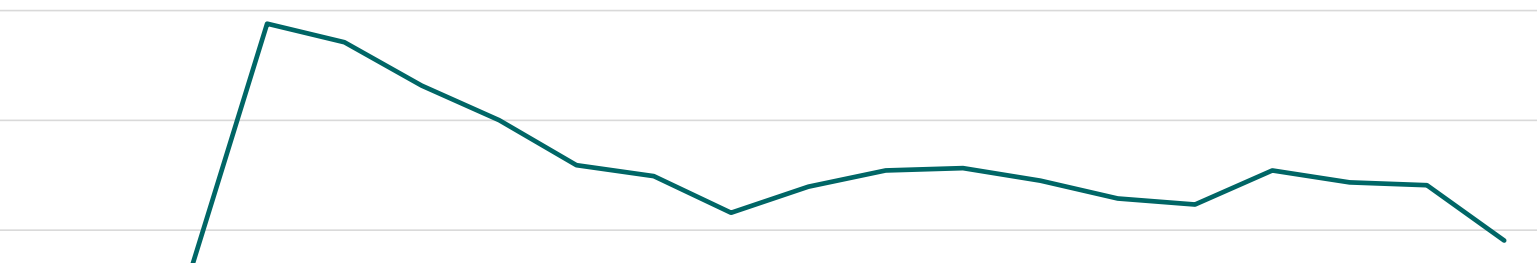

$4,000.0$

$2,000.0$

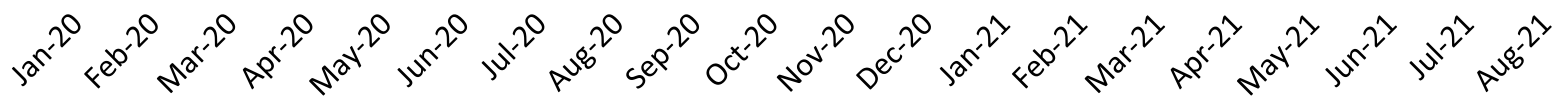

Source: U.S. Bureau of Labor Statistics' Current Population Survey Program. Not seasonally adjusted data.

Fig. 7 Persons out of the labor force who currently want a job, in thousands 
Between February and April, the size of the out of labor force group grew by 6 million (Fig. 7). It was a dramatic increase. There's a very large group of people that are out of the labor force currently, that can come back in the labor market, that I think get kind of lost in sort of the news coverage of the impact of the pandemic on the quote, "Unemployed," or what I call in this case, the near unemployed.

I'm going to look at it from two perspectives, one just the group itself. Females with less than a BA make up a disproportionate share of those who are out of the labor force (Fig. 8). Their employment share in February '20 was 27\%. Their share of the out of labor force group is now $45 \%$.

Another way of looking at it is to focus on a subset of the out of the labor force group: those who are currently out of the labor force, but want a job, and cite one of a variety of reasons as to why they can't look for work or take a job, such as childcare issues, they need training, they don't believe work is available in the area.

That's actually shown some progress (Fig. 9). That number rose dramatically during the recession. It's really come down. It was 7 million in May, but it was 5.8 million in August. So that's been some progress.

But, there's always a but. I went to the CPS tapes and focused on three reasons that are given for not looking for work: childcare, family responsibilities, and transportation. Those rose during the recession (Fig. 10). They've pretty much been stable every since. In terms of who is being affected by these problems, as of August ' $21,60 \%$ are females with less than a BA (Fig. 11). Hence, again, I see this as a recession that has really particularly hit those with less than a BA, with a particular emphasis on females and minorities.

\subsection{Evidence on labor shortages}

Part of the theme here, and what we're hearing from employers is, "We can't find workers." We do a lot of work at the Upjohn Institute talking about this with employers in the region. And it is a theme that I think is being repeated throughout the country.

Now certainly people are anxious to see what happens once the supplemental payments for UI are finished, the $\$ 600$, now down to $\$ 300$, and then gone. But, in addition, I think there's this notion that there's a mismatch going on between the skills that firms want and the skills that workers have.

I think long-term unemployment is a key aspect of what could be an emerging issue. I think it was definitely a big issue during the Great Recession. If you're going to look for evidence of a shortage, I could probably do 30 slides on that.

Think of what a shortage is. From theoretical perspective, I define it as the persistence of vacancies in the face of rising wages. In other words, the market tries to calibrate, but it doesn't. Well, theory doesn't really give you a lot of guidance as to what data to look at.

So I like to look at a variety of pieces of data. I'm going to show you two here. My list does not, but could, include things like overtime, and whether or not bonuses are

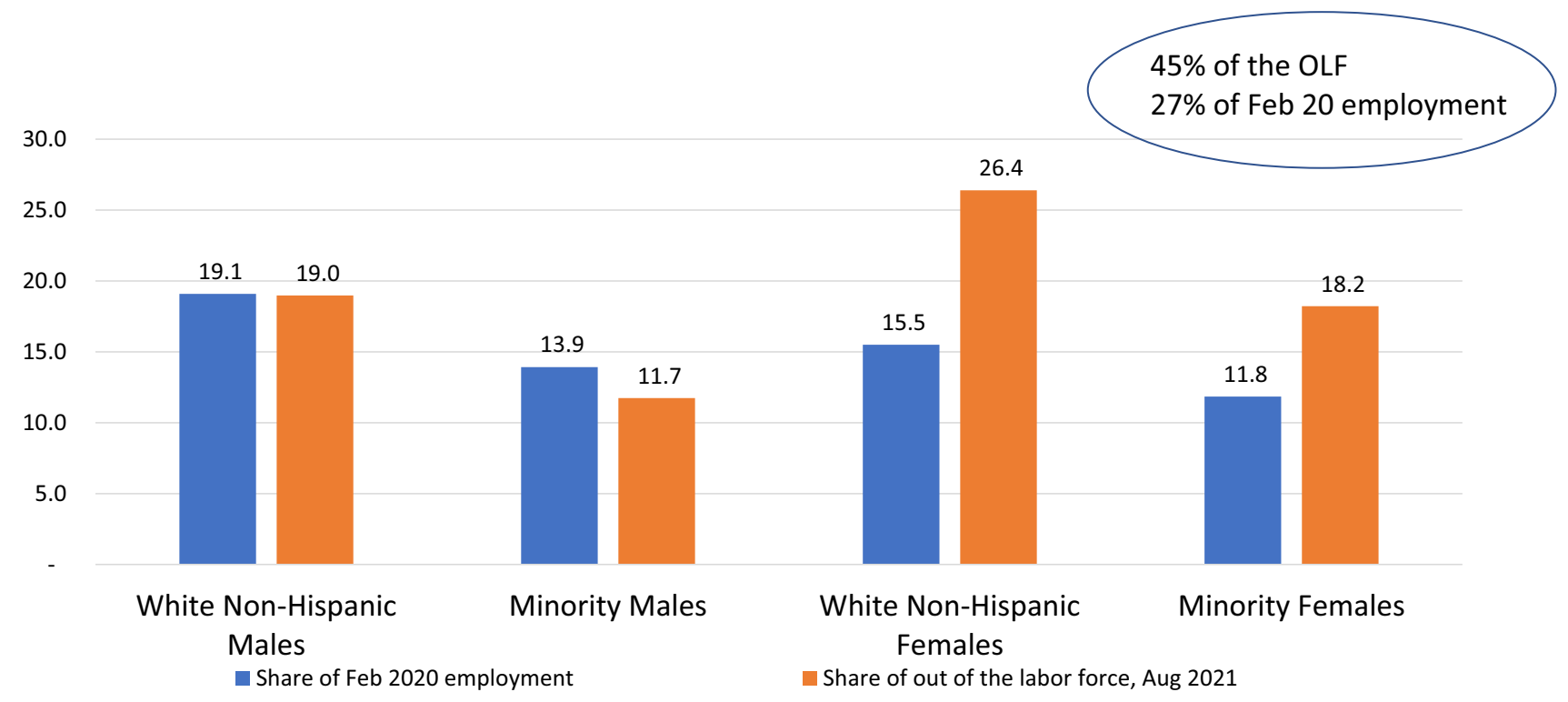

Source: U.S. Bureau of Labor Statistics' Current Population Survey Program. Not seasonally adjusted data.

Fig. 8 Females with less than a BA make up a disproportionate share of those who are out of the labor force 
$12,000.0$

$10,000.0$

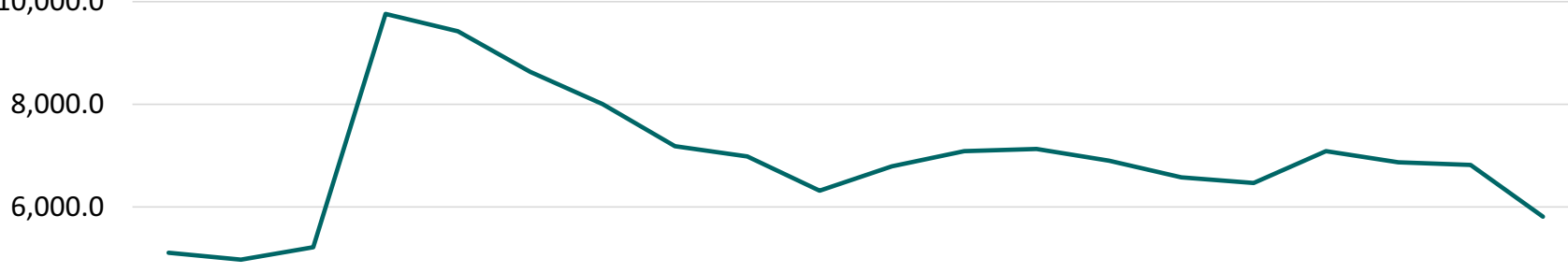

$4,000.0$

$2,000.0$

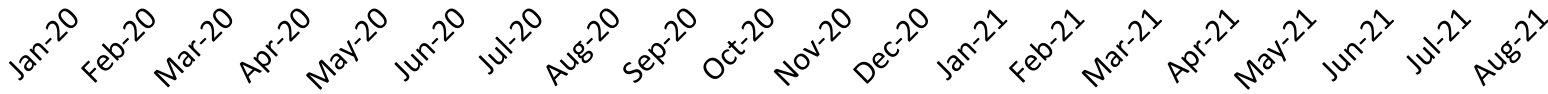

Source: U.S. Bureau of Labor Statistics' Current Population Survey Program. Not seasonally adjusted data.

Fig. 9 Number of individuals who are out of the labor force who report currently wanting a job now but cite a variety of barriers to looking for work, in thousands

$1,600.0$

$1,400.0$

$1,200.0$

$1,000.0$

800.0

600.0

400.0

200.0

0.0

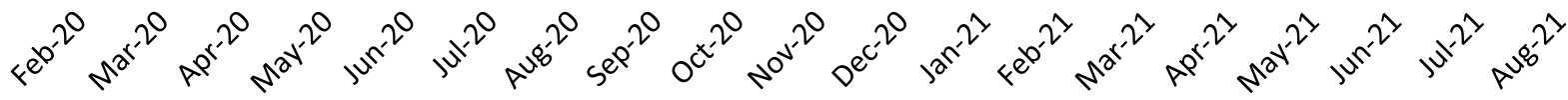

Source: U.S. Bureau of Labor Statistics' Current Population Survey Program. Not seasonally adjusted data.

Fig. 10 Number of individuals who are out of the labor force and currently want a job now but cited childcare, family responsibilities or transportation issues as barriers to looking for work, in thousands

being paid. The two I am going to look at are job openings relative to hires and whether or not firms are actually taking the step to increase their wage offers. The minimum wage in Michigan, for example, is $\$ 9.25$ an hour.

The average starting wage for a lot of occupations is much higher than that. So you can see there is a need, I think, in some markets to really increase wages. So what does the evidence show? Well, first what I'm going to show is how far back do we have to go in terms of employment?

We've got 5.3 million jobs left to fill to get back to pre-pandemic levels for (Table 2). I highlighted two rows here, professional and business services, and construction, because I'm going to use those two examples for the shortage data. 


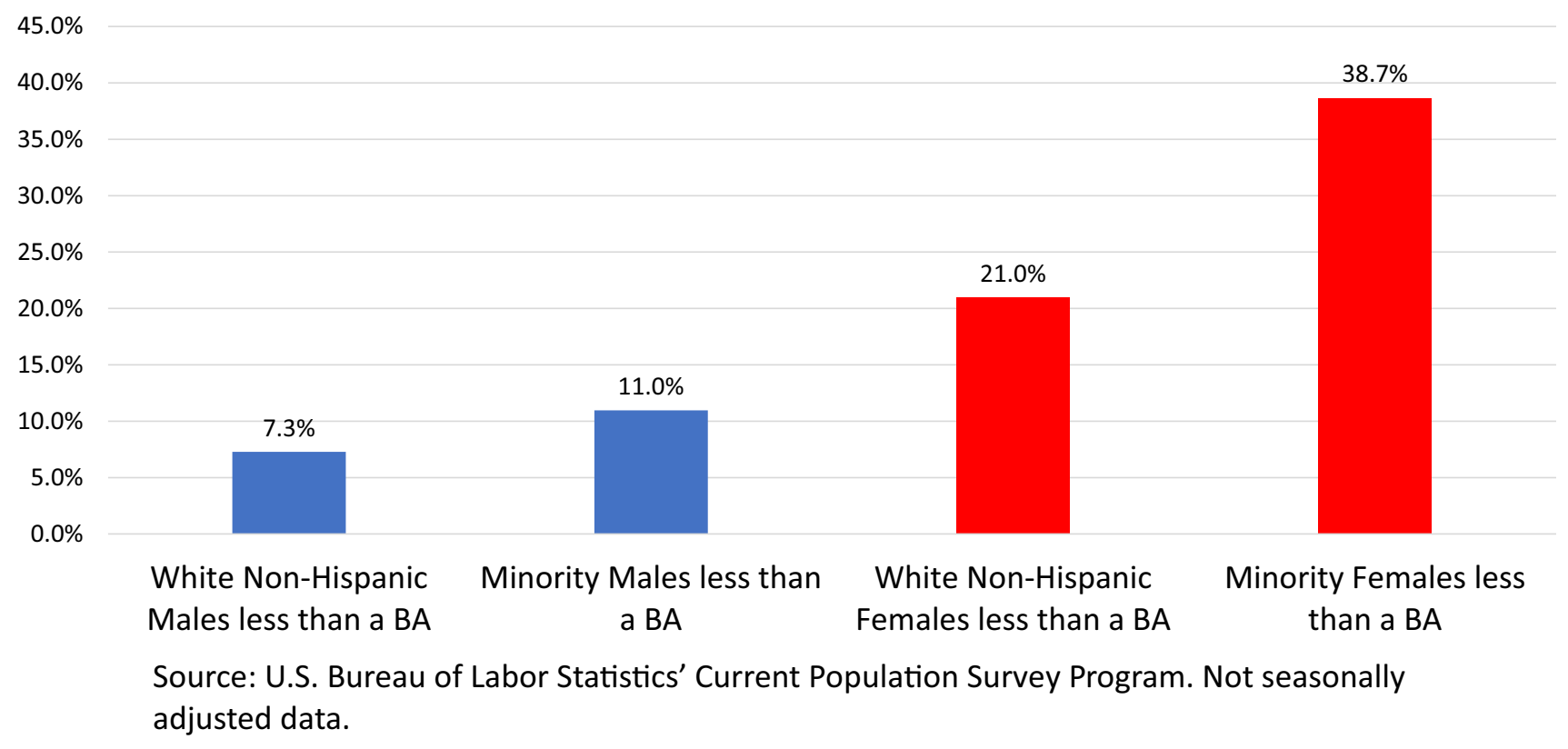

Fig. 11 August 2021 composition of Fig. 10 Group

Table 2 Job losses and gains by industry (thousands)

\begin{tabular}{lccc}
\hline Industry & $\begin{array}{l}\text { Job lost from Feb 2020 to } \\
\text { trough month }\end{array}$ & $\begin{array}{l}\text { Job gains from trough month } \\
\text { through June 2021 }\end{array}$ & $\begin{array}{l}\text { \# of jobs left to reach } \\
\text { pre-pandemic levels }\end{array}$ \\
\hline Non-farm & 22,362 & 17,029 & 5333 \\
Food Services and Drinking Places & 5975 & 5009 & 966 \\
Health Care & 1617 & 1103 & 514 \\
Professional and Business Services & 2387 & 1919 & 468 \\
Arts, Entertainment and Recreation & 1333 & 957 & 376 \\
Accommodation & 1015 & 659 & 356 \\
Retail Trade & 2375 & 2090 & 285 \\
Durable Goods Manufacturing & 945 & 672 & 273 \\
Temporary Help Services & 998 & 736 & 262 \\
Social Assistance & 701 & 468 & 233 \\
Construction & 1113 & 881 & 232 \\
\hline
\end{tabular}

Source U.S. Bureau of Labor Statistics' Current Employment Statistics Program, seasonally adjusted data

Let's first look at overall (Fig. 12). What I'm looking at here is JOLTS data, Job openings and Labor Turnover Survey. Basically, since late 2020, job openings have greatly exceeded hires. There's been this growing gap between openings and hires, which is one indicator, of many, of a shortage.

In terms of wages, look at Table 3. This is the change in average hourly earnings for all private employees. In April, it started rising. And it has been pretty steadily increasing ever since. This theme is going to get repeated for professional and business services (Fig. 13; Table 4).

It's almost identical. Rapid increase in job openings relative to hires starting in late 2020 , and wages, also starting in April, rising. But take a look at the employment gains. They're not as strong the rising wages; there are problems in the labor market in terms of making that match, in terms of getting the payroll employment gains that firms seem to want now that we have some semblance of normalcy, or getting some semblance of normalcy, out of the recession.

But if you look at construction, it's a completely different story. Openings and hires are in alignment (Fig. 14; Table 5). But despite that fact, wages also began to rise noticeably in April. And you can sort of see that alignment between openings and hires is revealing itself in very tepid and, in fact, negative payroll employment changes in most of 2021 . 


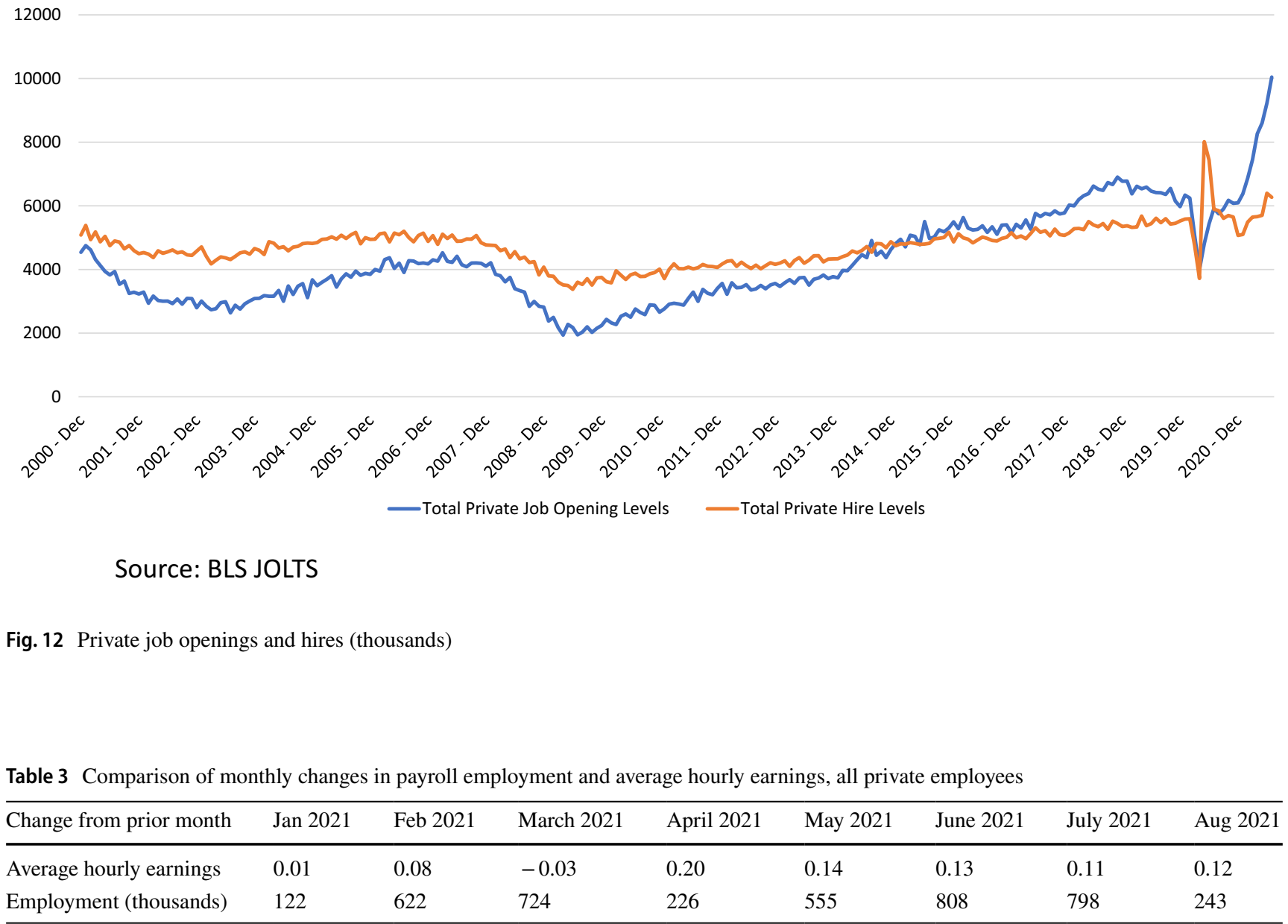

Source U.S. Bureau of Labor Statistics' Current Employment Statistics Program, seasonally adjusted data

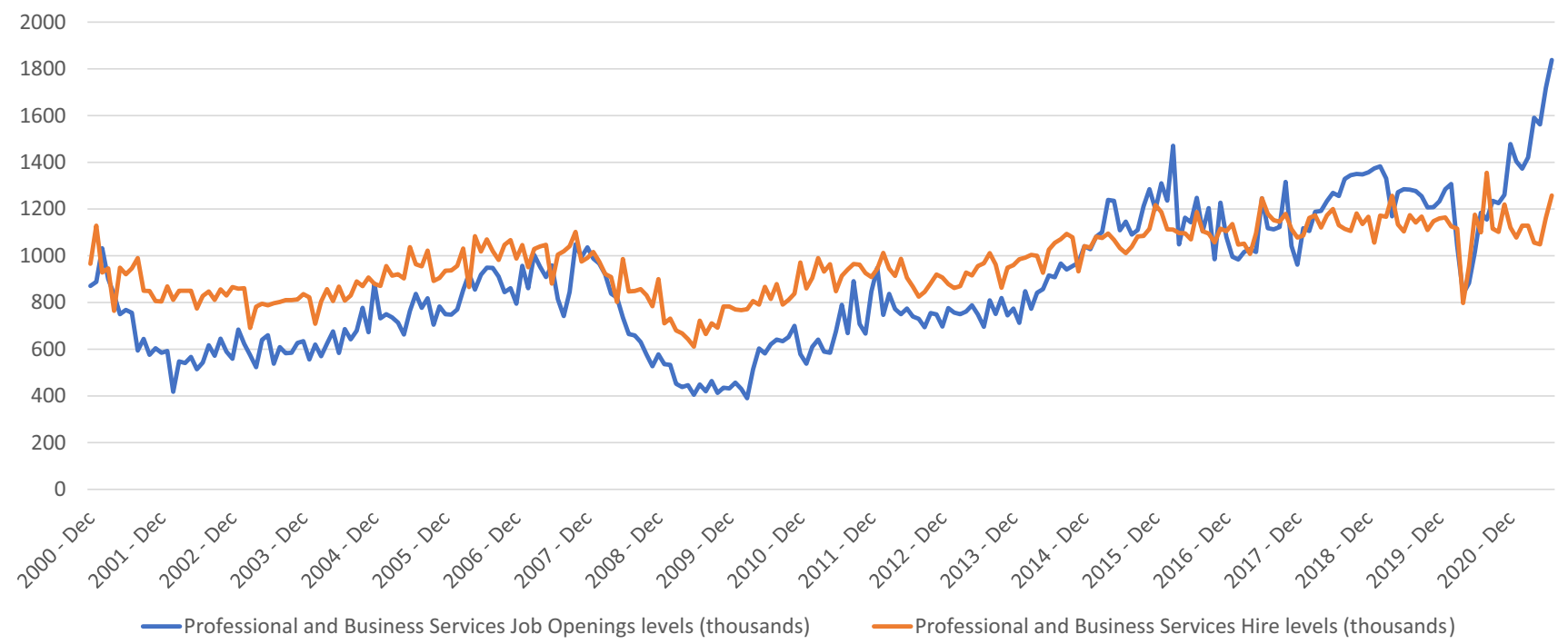

Source: BLS JOLTS

Fig. 13 Job openings have exceeded hires since late 2020 in professional and business services 
Table 4 Comparison of monthly changes in payroll employment and average hourly earnings, professional and business services

\begin{tabular}{lllllllll}
\hline Change from prior month & Jan 2021 & Feb 2021 & March 2021 & April 2021 & May 2021 & June 2021 & July 2021 & Aug 2021 \\
\hline Average hourly earnings (\$) & 0.08 & 0.16 & 0.07 & 0.26 & 0.30 & 0.16 & 0.18 \\
Employment (thousands) & 90 & 93 & 74 & -79 & 50 & 70 & 79 & 74 \\
\hline
\end{tabular}

Source U.S. Bureau of Labor Statistics' Current Employment Statistics Program, seasonally adjusted data

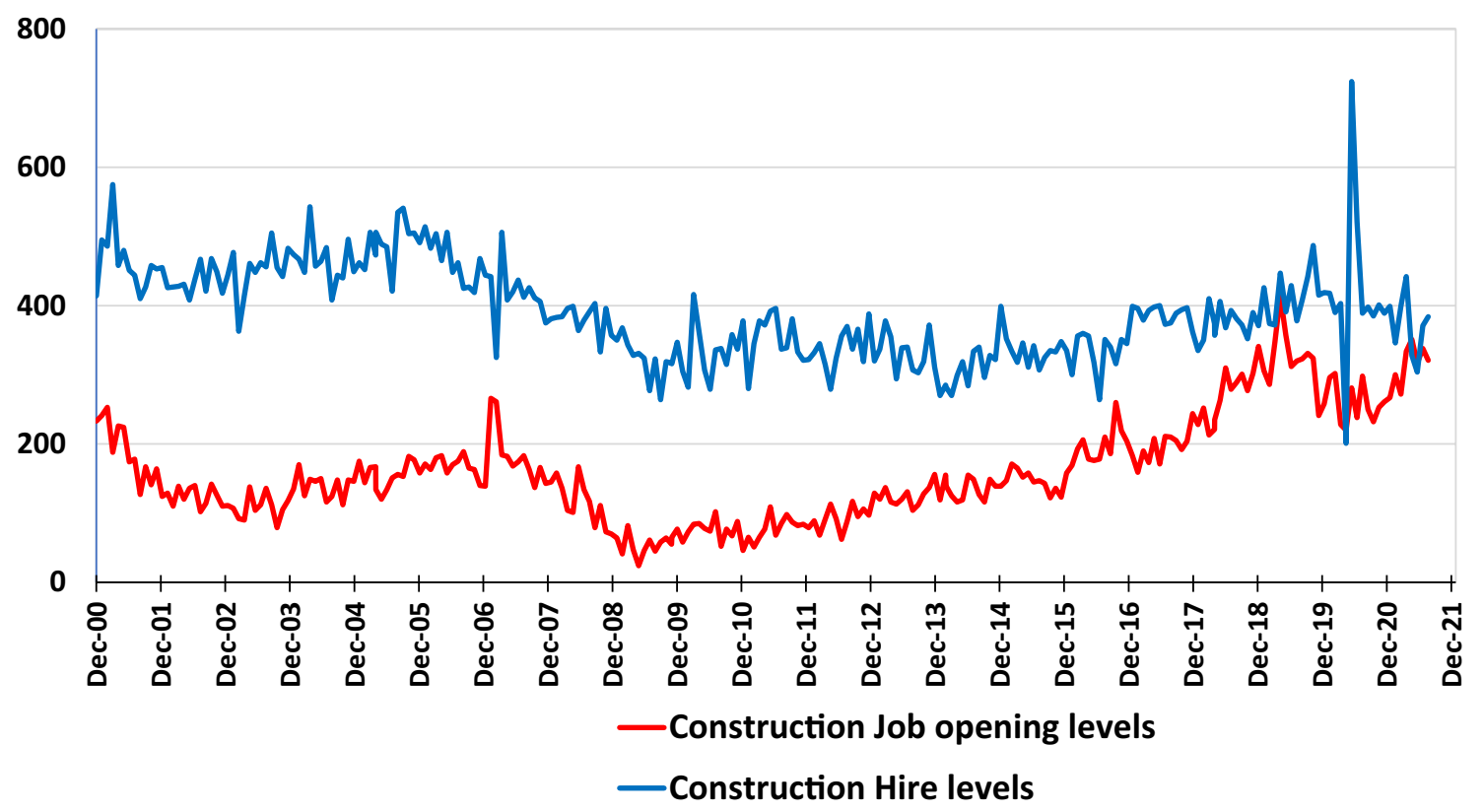

Source: U.S. Bureau of Labor Statistics JOLTS

Fig. 14 Job openings have caught up to hires recently in construction

Table 5 Comparison of monthly changes in payroll employment and average hourly earnings, construction

\begin{tabular}{lllllllll}
\hline Change from prior month & Jan 2021 & Feb 2021 & March 2021 & April 2021 & May 2021 & June 2021 & July 2021 & Aug 2021 \\
\hline Average hourly earnings (\$) & 0.08 & 0.11 & - & 0.31 & 0.16 & 0.11 & 0.09 & 0.12 \\
Employment (thousands) & 12 & -57 & 93 & -9 & -24 & -2 & 6 & -3 \\
\hline
\end{tabular}

Source U.S. Bureau of Labor Statistics' Current Employment Statistics Program, seasonally adjusted data

So obviously there's many other issues going on in construction, for instance in terms of supply chain issues, in terms of turnover. There's a lot more turnover. And there are also more contract employees who get hired, and not be captured in the actual construction industry data.

But it is interesting that in that industry, despite the fact that they're increasing wages, job openings are not as high or out of alignment with hires. The last slide (Table 6) just shows the trend across all industries. Basically the top two panels show all the industries that have openings that are either greatly exceeding hires, that top list, or they're recently outpacing hires, like in leisure. The two for which they're in line, construction and retail trade, are also industries for which there's a lot of turnover.

\section{Misty Heggeness}

Thank you for showing up today. I'm really excited. I feel very lucky to be here. I'm Misty Heggeness. I work as an economist and senior advisor for Evaluations and Experiments at the U.S. Census Bureau. My comments are my own and do not necessarily represent those of the Census Bureau.

I'm going to be talking about the supply side of our current labor market, with a focus on caregiving, and in particular I'm going to be talking about custodial mothers of school age children. I'm going to show you evidence I think complements what we've already seen.

The first thing that I want to say is that the labor market of today is not our grandmother's labor market. I am speaking 
Table 6 Industry openings and Hires

\begin{tabular}{l}
\hline Openings greatly exceed Hires in: \\
Manufacturing \\
Wholesale Trade \\
Professional and Business Services \\
Health Care and Social Assistance \\
Educational Services \\
State and Local Government \\
Openings recently began outpacing Hires in: \\
Leisure and Hospitality \\
Openings and Hires are roughly in line: \\
Construction \\
Retail Trade
\end{tabular}

specifically about women. One thing that kind of really gets a bee in my bonnet is this idea that women have left the labor market in droves.

You don't see it in the data, even at the beginning of the pandemic. But you do see women shifting out of active work status into either paid or unpaid leave or unemployment.

I'm focusing on custodial mothers of school age children. The reason is pretty simple. Before the pandemic, they had a safe, developmentally appropriate, space for their children to be in during the day. Since public schooling is very accessible, usually it didn't cost parents a whole lot of money to have their kids in school.

But then we approach March of 2020 and the pandemic hits. Figure 15 shows the trends for custodial mothers' employment status. The bottom portion are mothers who are out of the workforce. So they're not working. They're not actively looking for work.

What you see here is that there's not a gigantic amount of difference pre- and post-pandemic in whether or not custodial mothers were engaged in the labor force. The line above that is mothers who went on leave. And so what you do see is a big shift up in terms of mothers going on leave to deal with the childcare issues that they had in their households.

And so just to kind of clarify this or put numbers around it, there was a 3.9 percentage point increase in exits from the labor force between February and April of 2020. There was a 7.1 percentage point increase in unemployment for these moms. The third range is paid and unpaid leave: there was a 4.5 percentage point increase in paid and unpaid leave of custodial mothers.

What you also do see in the data is that moms do tend to exit during summer months or when their kids are on vacation. You do see those kind of pyramids going on in the data both pre- and post-pandemic. And so what happened when the pandemic hit was moms left work earlier than they normally would during the year and they stayed out longer. But they stayed out either in leave or unemployment.

I'm really interested in how much of moms' inability to work or actively work was due to this childcare issue. Figure 16 shows CPS data for the months before and after March of 2020. The bars show differences in labor market participation between prime age custodial mothers of school age children compared to women without any dependent
Fig. 15 Employment status of custodial mothers

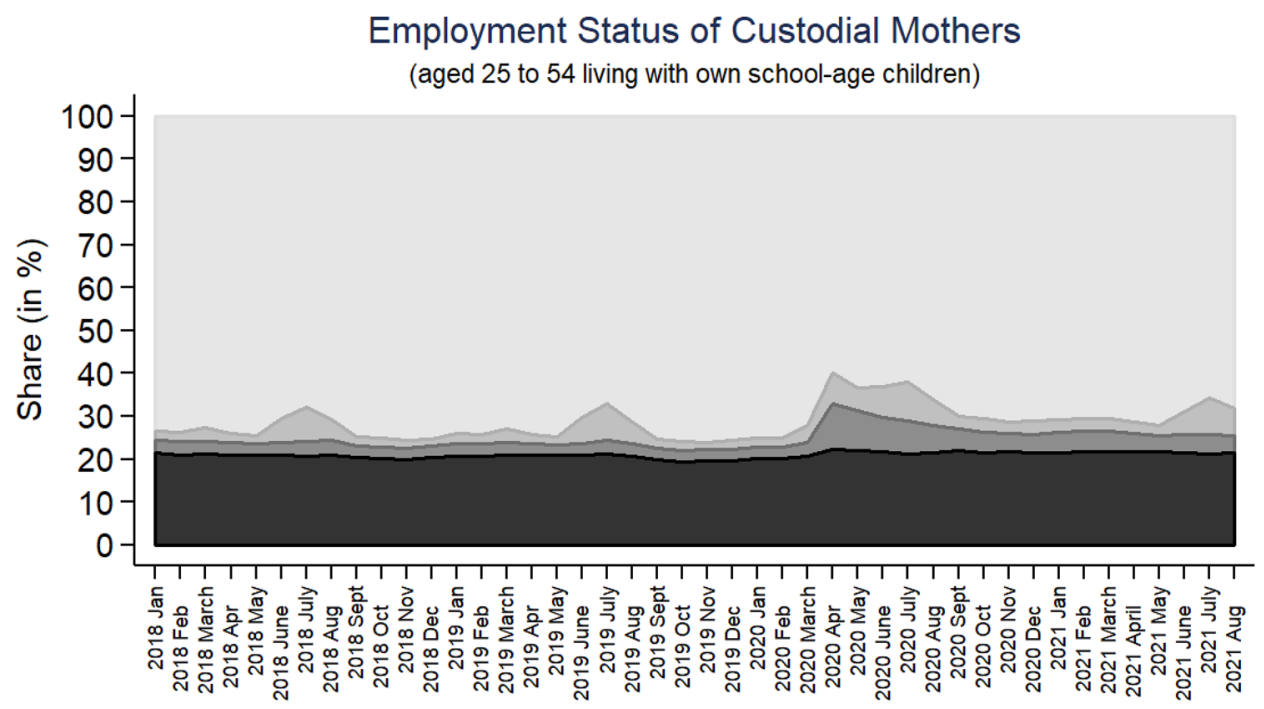

Graph shows the share of custodial mothers in each category. 


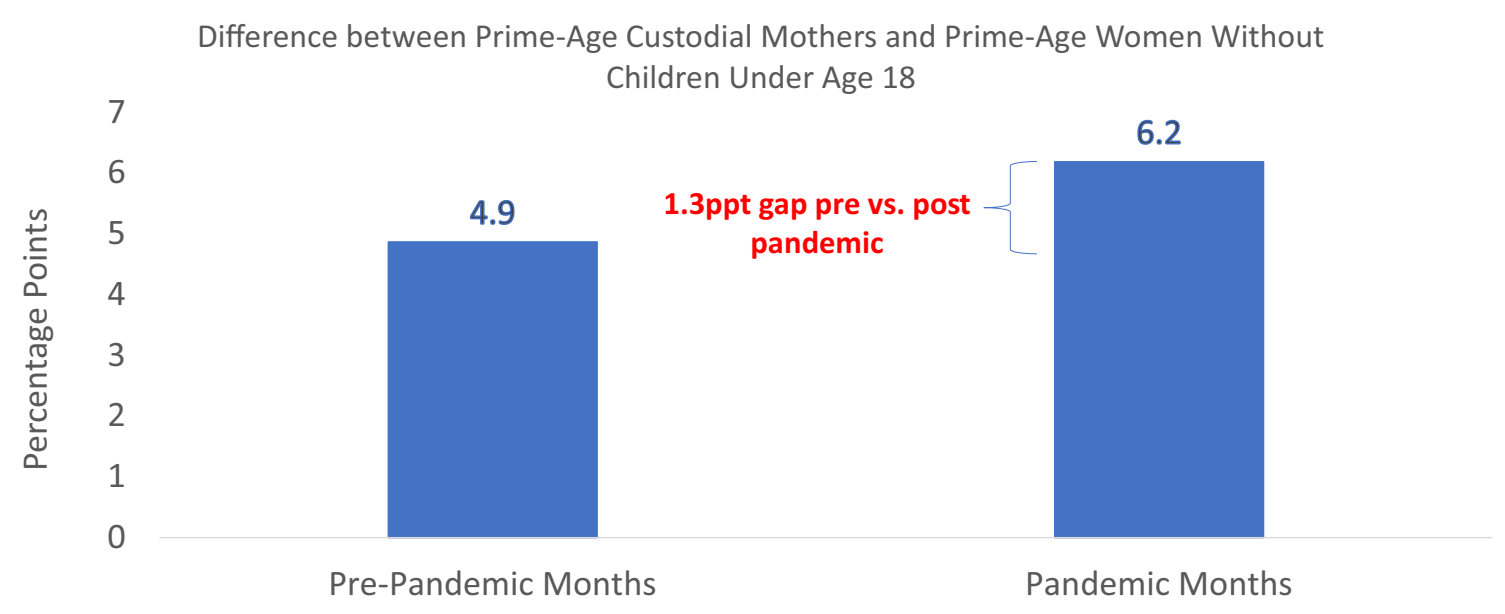

Fig. 16 What proportion of pandemic labor force exits is due to childcare?

children; those women who don't have any dependent children in their household under age 18.

And in the pre-pandemic months, you can see that moms were more likely to be out of the labor force, 4.9 percentage points. And during pandemic months, that increased to 6.2 percentage points. So there's a gap there of 1.3 percentage points pre- and post-pandemic in terms of mothers' labor force participation compared to women without children.

I'm going to now decompose this 1.3 percentage point gap (Fig. 17). If we add in some fixed effects for geography and whether or not there's another prime age adult in the household, so somebody else who can go out and work, that gap reduces to 1.2 percentage points. If we control for educational attainment, the gap decreases to 0.9 percentage point. And then if we control for differences in job and industry classifications between mothers of school age children and women without children, this gap drops to 0.1 percentage point. So there is a 0.1 percentage point drop in the difference between custodial mothers and women without children that we can basically attribute to childcare issues.

I'm a mom. I have an 11 and a 13 year old. And I'm stressed and I'm exhausted all the time. But I stayed working. And I had the privilege to be able to tele-work and keep my job, while at the same time balancing all the additional work that was happening within my household.

I think what we need to do today is that we need to reframe how we think about women in the labor market. There are lots of news stories about childcare as a major issue. And it is. I will argue why it's even more important of an issue today, but not because women are exiting the labor market. It's an issue because they are not exiting. They're all stressed.

We really need to reframe and rethink women's labor supply post-pandemic. And, again, I will just articulate that we

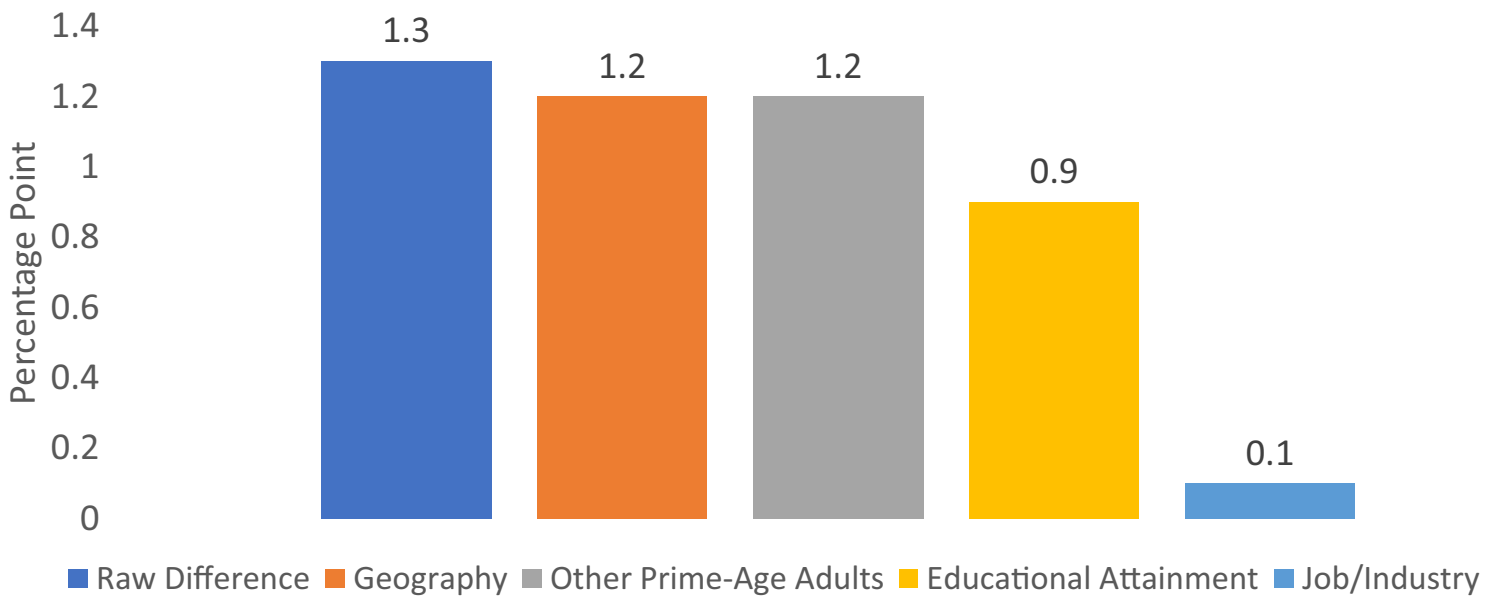

Fig. 17 Pandemic exits due to childcare 
no longer live in our grandmother's labor market. We live in a labor market where women are working and rely on their income for survival. Households today, at least in the US, but I think this is not just unique to the US, rely more and more on more than one income for survival. And so a lot of the reasons why women haven't entirely left the labor market is because they don't have the ability to leave, because their income contributes to putting food on the table, a roof over their family's head, clothes on their children's backs.

This is true for middle-income families. And it's also true for a lot of upper middle-income families. It really is a luxury these days to be able to live in a family with a oneincome household.

Women have higher levels of education than ever before, and women identify with career and work more than they ever have in the past. So even if, in my household, we would be able to survive off of my husband's income alone, my stepping back from my career is not just a reduction in income, it's also a very serious shift in who identify myself as, as a human being.

And so, as I just said, women identify with careers and work more than ever before. Young women expect to have both careers and families. Nobody's telling them differently. And so you see a lot of young women getting really, really stressed when they actually do become pregnant and have to make these life-altering decisions around work and family.

We're not setting them up for success. So women are burnt out today precisely because they did not exit the labor market in droves, but yet they still provided disproportional care efforts within their households. Where there's discussions about really stressed-out moms, moms struggling, all these different things, one of the reasons why they're so stressed out is because they continued to work.

Because of all these facts, I'm a huge proponent of affordable and accessible childcare for all. I really think that's one of the ways in which we as a society can start to eliminate some of the gender disparities both at work and at home.

\section{Kate Bahn}

I really appreciate those different perspectives. I think the overall takeaway is this is a very unique recession, and a very unique rebound.

It's really complicated right now. As Mike mentioned, $76 \%$ of jobs have been regained. We have had historic levels of job openings. The last month of data was from July where there were 11 million vacancies, compared with 8.4 million unemployed workers, along with another 5.7 million discouraged workers who said they would go back to work, but have not done so.
Surveys have found that many of these job seekers aren't finding good job opportunities, with $46 \%$ saying that they are only finding low-paid openings. So they're not going back to work, because they're just not good job opportunities for these workers.

In terms of looking at the policy landscape, how do we get workers back to jobs? And, particularly, how do we foster really sustainable long-term job matches? We want to make sure that workers are getting into good jobs and staying in those good jobs, rather than return to a previous era of turmoil and fragility in the labor market where workers may have faced a lot of turnover, not sustainable job options, not a lot of occupational mobility, so not moving up the income ladder, or into better matches in new occupations.

One of the common arguments on how to get people back to work is to improve skills. Of course, skills are important. But they are necessary but not sufficient is the argument I make. For about 70 years, employers have been arguing that "Oh, the reason there's a labor shortage is because we can't find skills." The sort of cynical part of me is that this really shifts responsibilities to workers to increase their training, often at great cost, with no guarantee of better outcomes.

We find particularly that workers of all races and ethnicities have been increasing their education levels, and it has not translated into higher earnings or better job opportunities. In particular, black workers have been increasing their education levels over the past 20 years, while black/white wage divides have increased over the past 20 years. Black/ white wage divides are higher at higher levels of education. So education clearly has not been sufficient to improve those job match outcomes. And employers don't appear to be offering wages to incentivize the types of training investments they expect of workers. So they are not offering a marketclearing wage.

One of the common arguments in economics is that there's been restructuring in the labor market that has increased demand for higher skilled workers, and that is why we've seen rising income inequality, and that's why we see some of this mismatch.

But there's more recent evidence that skill-biased technical change has lost its explanatory power since the year 2000 (Autor et al. 2020). Other explanations for the mismatch are of the kind that worker power is decreasing. There is a well established inverse relationship between union density and income inequality.

This might be part of the reason why there are not highquality jobs on offer to many different workers, and limited workers' job opportunities. And also, structural racism and sexism appear to dominate wage outcomes and job matches for many workers, both leading to disadvantages for some workers and privileges or premiums for other workers.

We've done work at Equitable Growth where we look at the gender wage gap by different race and ethnic breakdowns 
for women. We do things like comparing Latina women workers, and Black women workers, and Asian American women workers, to white men. When you particularly look at the subgroups of workers who are the ones who, as Mike had said in his presentation, really seem to be suffering the hardest, they are workers with less education, but particularly women and minority workers.

When we look at that the reason they have lower wages, over half of the wage gap for those minority women worker groups is due to unexplained factors or what we might interpret as discrimination. What we find is that if you decompose wages where you're looking at, for example, black women compared to the population of workers, and then white men compared to the population of workers, that white men's higher earnings are not due to their human capital variables.

These effects, sexism and racism, influence wage outcomes on both sides of the wage distribution. I want to also call attention to one specific type of job that has been both impacted in this pandemic, but has had a long-term impact on the labor market, which is paid care work.

There's increasing demand for paid care work, particularly at the low end of the wage spectrum. These jobs require high levels of skill. They provide significant positive externalities.

But they face structural market failures. And so I think they're sort of best served through support to assure both quality and fair pay, particularly for these care situations where we think that there's a big positive externality by having adequate care provision through paid care workers.

Deregulation limits the quality of care work. We want to make sure we're not limiting quality of care work that's being provided for folks, so that we have those long-term externalities from having adequate care provision. So what are the policy solutions? That is actually what I'm supposed to be talking about here. Creating jobs is obviously a good first thing to do. Physical infrastructure is one piece of that. We're using the term now at Equitable Growth, social infrastructure, which is sort of those types of care jobs that are those that make other jobs possible.

Physical infrastructure is part of the bipartisan infrastructure deal. And social infrastructure has been put into the Reconciliation Bill in a number of different ways. We need to really ensure that we're expanding supports for caregiving across the life cycle and for different care needs.

These are complements and not substitutes. And so when we talk about providing both direct care services, there is expansion of support to paid care services in the reconciliation package for both childcare expansion and also home and community based care services. Those might be care services that are used for ill family members, family members who otherwise can't care for themselves. Those are really important for families to be able to balance care need too. Because it can't all be done by paid care workers.

We need, I think, a suite of the types of policies that allow for families to do this. Again, these things are complements and not substitutes. We need things like paid leave, paid sick leave, predictable and flexible schedules.

So, narratively, you take time off at the birth of a child. We definitely need paid leave so people can do that and maintain their labor force attachment. But then what happens a year later when you have a toddler who gets sick? You need to be able to have access to paid sick leave so that you can take care of your family.

And, likewise, you need a predictable and flexible schedule, so you can try to shape your work schedule around access to caregiving. Many workers may not have predictable schedules. A lot of childcare centers run on a typical sort of 9:00 AM to 5:00 PM work schedule. That is not what many families actually are doing. And then if you don't have a predictable work schedule, so you may have to sign up for a full week of childcare, but then your shifts get canceled, and you still have to pay for that. And so we really need this broad suite of things to address the life cycle of caregiving within families.

Another area of policy that I think is really critical is income support. There's sort of a typical narrative that income supports are a disincentive for work. I think the empirical evidence suggests precisely the opposite, that providing a stable foundation is exactly what we need to ensure good job matches, those sustainable, long term, high-quality job matches that we want workers to have access to.

So, for example, unemployment insurance extended benefits has been shown to improve job matches, decreasing the mismatch between a workers' education attainment and job educational requirements. So, for example, say you just graduated college. Maybe you worked 1 year in an office job. You lost your job. If you have better access to unemployment insurance, you can take time to search for a job that matches the education level you have, rather than perhaps, you going and working in a café and getting stuck in a different range of occupations that might not be the best for your long-term income growth.

In this research on unemployment insurance extended benefits, the effect was also particularly greater for women and non-white workers who are more likely to be credit constrained and facing job search frictions, both historically, but also particularly in the current moment.

Likewise, it's not income support per se, but Medicaid expansion has been shown to have the same effect of improving job matches. There's more occupational mobility into high wage occupations in states that had expanded Medicaid compared to those states that did not.

There's also research evidence about how low-wage workers who are in poverty households are less likely to move to 
better wages, compared to low wage workers not in poverty households. So this would argue for anti-poverty programs that help families and households get out of poverty, precisely so those low wage workers can move up into higher paid occupations.

I would also argue that unions are an effective institution for many ends that help people get back into good jobs. If the labor market is monopsonistic, if we don't have a competitive labor market, employers would often undercut wages. Having institutions like unions to help bargain over wages actually gets the labor market to a place that would be sort of replicating what would happen in a competitive outcome. Unions can be really effective in that. They're also effective partners in labor standards enforcement and workplace safety.

Again, substitutes but complements. Unions make OSHA operate more effectively. They reduce turnover for workers. Turnover has a really high cost for employers, particularly in the current moment. Employers really want to have lower levels of turnover.

More recent evidence also suggests that unions increase job satisfaction. The reconciliation package has some measures right now (editor's note: as of September 2021) that try to make unions more accessible. There's a union dues tax deduction. There are increases in the damages the National Labor Relations Board can levy against employers. Research has shown that the damages for violating the right to organize are so low for employers that they have literally no reason to not violate workers' right to organize. They only have to pay back wages. If you only have to pay back wages, there's literally no reason for you to not fire a worker who is trying to organize a union, even if it is illegal for you to do so.

But there is the need for broader labor law reform, and particularly to address modern phenomena in the labor market, like fissuring. Fissuring is the phenomenon where companies outsource to subcontractors. We need to make sure that we have labor law that reflects these modern employment relationships, so that unionization and holding employers accountable is more accessible to more workers.

One more thing: targeting structural racism and sexism is really important. I think some policies, like income supports, do help that; it gives people the stability and the foundation to find better jobs.

But we need things like effective anti-discrimination enforcement. It's particularly important for women of color, particularly important in fragile labor markets like what we have right now.

These moves work in tandem with other policies. For example, there's evidence that shows that when North Carolina reduced their unemployment insurance benefits levels, there was a decrease in sexual harassment claims in North Carolina. When workers are afraid of retaliation, when they don't have good outside options, such as when there's not sufficient unemployment insurance, they're less likely to access the protections that they are entitled to, because of the lack of income support and lack of stability.

There's been a lot of progress. What has been done so far in the past year and proposed in the reconciliation package is revolutionary. But there's still a lot more work to be done.

\section{Michael Strain}

Well, first of all, let me congratulate NABE for doing this. It's wonderful to see people in three dimensions.

I will begin by asking a very basic question, is the labor market hot or cold? This is debated a lot. On the one hand, we have record job openings. On the other hand, labor supply, as measured by the workforce participation rate, really hasn't recovered in a year or longer.

What's the best way to think about the state of the labor market? Should we measure labor market strength fundamentally looking at the growth rate of wages? And if so, what does that tell us? I think all of these ways of assessing this really centrally important question have advantages.

They would be sufficient in a normal labor market. We are just in a very abnormal labor market. The normal ways that we think about the state of the labor market, I think, are helpful but not dispositive in the way that they normally would be.

The good news is that, almost by definition, means that we're in a temporary situation. We have a situation where, not just in the labor market, but throughout the economy, the demand side of the economy is booming. That is driven by reopening from lockdowns, a reopening that began over the summer.

That's a situation that is not going to last. The demand side of the boom is driven by households sitting on over $\$ 2$ trillion of excess savings and wanting to go out and spend that money. That situation is not going to last. Those savings are going to be depleted.

The situation is driven, of course, by substantial income support from the federal government, including nearly $\$ 3$ trillion of support in calendar year 2021 between the $\$ 900$ billion that President Trump signed in December and the $\$ 1.9$ trillion that President Biden signed early in his term.

That is not going to persist. So I think we should think about the demand side of the economy as cooling. At the same time the demand side of the economy is cooling, the supply side of the economy should pick up.

People are still sitting on the sidelines out of concern about the coronavirus. That was very clear if you look at data from the August employment report. That situation, fortunately, looks like it's not going to persist. There's good reason to believe we've hit peak Delta caseloads and that 
concern about being infected with COVID should subside along with those case numbers.

In my view, the best forecast for the effect of nearly doubling the generosity of unemployment benefits is that it will keep a non-trivial number of workers on the sidelines. The last estimates I saw, roughly half of unemployed workers had a higher income from unemployment benefits than they would have had from working.

That's going have an effect on labor supply, in my view, based on the half century of evidence we had prior to the pandemic. That program terminated earlier this month. My reading of the evidence is that problems securing childcare are still pretty substantial in keeping people out of paid employment.

Hopefully that clears up as we move through September and into October as well. That I think is the big X factor. So you have a situation where demand will cool, supply will strengthen. That will bring the labor market more into equilibrium.

A lot of the problems that we are having I think should subside over the course of this calendar year. What will public policy do to that? I think if we do have a government shutdown and we do have a default, or at least we run up to the $\mathrm{X}$ date for the debt ceiling, that should cool the demand side of the economy.

Not a reason to do it. But, macroeconomic policy interacts very weirdly with the labor market at times. And beyond the current week and 3 weeks of high drama and near civilizational collapse that we're in for, I don't really view the $\$ 3.5$ trillion reconciliation package as doing a whole lot to help these problems.

First of all, these problems are short-lived and temporary. I think we're going to be well beyond this current moment of disequilibrium by the time any piece of legislation that is designed to create and expand new social programs, and raise taxes, and do all that stuff, actually kicks in.

More than that though, I think that the provisions in the bill are not really well structured to address the challenges that will outlast the pandemic and that existed before the pandemic. Healthcare security, for example. I think if we could do a better job giving Americans healthcare security, that would have a good effect on the labor market.

It would help people to participate in the workforce. These are good things. Simply dumping billions of dollars into the Medicare program without really changing the structure of the Medicare program is not going to really give the workforce greater healthcare security.

I think Washington should be paying attention to childcare issues. I think making childcare more accessible, making childcare more affordable would be a big help to the labor market. It would help people to participate in the labor market. And it would help families with the stress of being working parents, and do all sorts of great things.
Offering a open-ended subsidy to households to spend on commercial childcare, which is what it looks like Congress is going to try to do, I don't really see helping the people who need help the most. Commercial daycare is great. It's really not what everybody needs.

People who work irregular schedules, people who work evenings, people who work weekends are not gonna be helped by a daycare that closes at 5:00 PM, a point that was made earlier. Moreover, substantially increasing the demand for commercial childcare without addressing the supply of commercial childcare will just push up the price of commercial childcare and won't really work to increase the availability of childcare nearly as well as a bill with supply side reforms.

I see a lot of good kind of intentions in the president's agenda. I think that these programs would all be made better if Congress slowed down, took a breath, tried to talk to people, tried to figure out how to structure them better, instead of just trying to ram them through.

Over the longer term what will help? I think the infrastructure bill, that addresses physical infrastructure, infrastructure traditionally understood, along with broadband, I think will help the economy quite a bit over the next decade through all sorts of things, by making it easier and more profitable for businesses to do business by helping workers to have clean drinking water, and helping workers to have access to broadband, and all sorts of stuff.

The bill is designed as a supply side bill to spend out over 8 or 10 years and to really focus on improving the productive capacity of the economy, which is I think the right way to think about infrastructure. So I hope that passes. Smart macroeconomic policy is really important.

We, I think, learned from the expansion following the 2008 global financial crisis just how important it is to let the economy run hot. If you look at the path of the expansion, if it had ended in 2014, 5 years after it officially began, then we would have had a situation where the bottom half of workers had lower wages at its end than they had in 2007, immediately prior to the recession.

If the expansion had ended in 2015, by 2015 the median had risen above its 2007 level, but the bottom $20 \%$ had not. It really was only in 2016, 2017, 2018, 2019 that you really saw a rising tide lifting all boats. And fortunately, because of the longevity of the expansion, the benefits of it really did reach workers at the bottom of the income distribution, reached workers who are traditionally vulnerable workers, like workers with disabilities and workers with criminal backgrounds.

So smart macroeconomic policy is important. I don't think we have had smart macroeconomic policy under President Biden. The American Rescue Plan was four or five times larger than it should have been given the output gap. And I think it is responsible for a large share of 
both the overheating demand side of the economy and the restricted supply side of the economy.

Beyond macroeconomic policy, I think we really need to do things to help people participate in the economy, smart childcare would be one, income supports, I completely agree with Kate, programs like the Earned Income Tax Credit, I think really have been shown not only to fight poverty, but also to increase workforce participation.

There are smart things we can do for parents. We should be thinking, I think, about a kind of baby bonus when a parent welcomes a new child. Is there a way for a program to redistribute some income to them to help them take time off from the workforce or to help them to afford arranging for childcare, to help them to kind of handle that tumultuous period of life?

We need to really be serious about skills. We need to be serious about deregulating the labor market to increase competition, things like occupational licensing reform and other kind of classic barriers to entry, monopsonistic employer practices, which Kate mentioned as well, that serve to reduce competition in the labor force really should be addressed. I could keep going. But I will not. Thank you.

\section{Reference}

Autor, David, Claudia Goldin, and Lawrence F. Katz. 2020. Extending the Race Between Education and Technology. American Economics Association Papers and Proceedings 110: 347-351.

Publisher's Note Springer Nature remains neutral with regard to jurisdictional claims in published maps and institutional affiliations.

Michael Horrigan is President of the Upjohn Institute. He took over as the Upjohn Institute's President in March 2019. He served previously as Associate Commissioner with the Bureau of Labor Statistics. Horrigan came to the BLS as a Labor Economist in 1986, after 6 years as an Economics Professor at Williams College in his native Massachusetts. He rose through the ranks as a Division Chief, the Director of the National Longitudinal Surveys Program, and Assistant Commissioner in two offices. He served as Associate Commissioner for the Offices of Prices and Living Conditions before taking his role of Associate Commissioner in the Office of Unemployment and Unemployment Statistics in 2014
Misty Heggeness is Principal Economist/Senior Advisor for Evaluations and Experiments, U.S. Census. She has over two decades of experience working with complex, nationally representative household survey data, decennial census data, and administrative files. Her experience includes cleaning, merging, linking, restructuring, and organizing large nationally representative data, as well as multiple research projects using impact evaluation and econometric tools to analyze outcomes, policies, and procedures. She has over a decade of experience in the federal government that includes leading economic research, as well as managing staff workload, large grants, contracts, and interagency agreements, and established networks with key stakeholders in the Department of Labor, the U.S. Census Bureau, the Bureau of Economic Analysis (BEA), and the National Institutes of Health (NIH).

Kate Bahn is the Director of Labor Market Policy and Interim Chief Economist at the Washington Center for Equitable Growth. Her areas of research include gender, race, and ethnicity in the labor market, care work, and monopsonistic labor markets. Previously, she was an Economist at the Center for American Progress.

Michael R. Strain is a Senior Fellow, the Director of Economic Policy Studies, and the Arthur F. Burns Scholar in Political Economy at the American Enterprise Institute (AEI), where he oversees the Institute's work in economic policy, financial markets, international trade and finance, tax and budget policy, welfare economics, health care policy, and related areas. Dr. Strain is the author of The American Dream Is Not Dead: (But Populism Could Kill It) (Templeton Press, 2020). Before joining AEI, Dr. Strain worked in the Center for Economic Studies at the U.S. Census Bureau and in the Macroeconomics Research Group at the Federal Reserve Bank of New York. Dr. Strain's research focuses on labor economics, public finance, and social policy, and his papers have been published in peer-reviewed academic journals and policy journals such as Tax Notes and National Affairs. He is the Editor or Coeditor of three books: What Has Happened to the American Working Class Since the Great Recession? (American Academy of Political and Social Science, 2021); The US Labor Market: Questions and Challenges for Public Policy (AEI Press, 2016); and Economic Freedom and Human Flourishing: Perspectives from Political Philosophy (AEI Press, 2016). He was a Member of the AEI-Brookings Working Group on Poverty and Opportunity, which published the report Opportunity, Responsibility, and Security: A Consensus Plan for Reducing Poverty and Restoring the American Dream. He also writes frequently for popular audiences, and his essays and op-eds have been published by The New York Times, The Wall Street Journal, The Washington Post, The Atlantic, National Review, and The Weekly Standard, among others. $\mathrm{He}$ is a columnist for Bloomberg Opinion. A frequent guest on radio and television, Dr. Strain is regularly interviewed by news networks, including CNBC, MSNBC, and NPR. He has testified before Congress, and speaks often to a variety of audiences. Dr. Strain has a PhD in Economics from Cornell University. He is a graduate of Marquette University and holds an MA from New York University. 